\title{
References:
}

1. P. A. Kragel, A. R. Knodt, A. R. Hariri, K. S. LaBar. Decoding Spontaneous Emotional States in the Human Brain. PLOS Biology, 14(9): e2000106, (2016) https:// doi.org/10.1371/journal.pbio.2000106 (Accessed 25 August 2020).

2. A. Walter. Designing for Emotion. Book Apart, New York (2011).

3. D. Norman. Emotional Design: Why We Love (or Hate) Everyday Things. Basic Books (2005).

4. Analiticheskij doklad "Uroki "stress-testa": vuzy v usloviyah pandemii i posle nee" [Analitical report The outcomes of stress test: universities during the pandemic and after it"] Minobrnauki RF [The Ministry of Education of the Russian Federation] (2020). https://drive.google.com/file/d/1GMcBIoP8ITzE_WDVh4nFksX6lceotZY3/ view (Accessed 25 August 2020).

DOI 10.15826/B978-5-7996-3081-2.04

\section{Creativity as a Challenge in the EFL Classroom}

\section{Belyakova Irina' ${ }^{1}, K^{2}$ cherukova Marina ${ }^{2}$}

${ }^{1}$ The University of Tyumen, Tyumen, Russian Federation

${ }^{2}$ The Industrial University of Tyumen, Tyumen, Russian Federation

Corresponding author: Belyakova Irina E., i.e.belyakova@utmn.ru

Abstract. Creative skills have been a lot in the limelight of pedagogical research recently. Creative tasks have become an integral part of modern textbooks including those for foreign language studies. The authors link the relevance of students' creativity with the growing need of the Russian economy for individuals who can think outside the box, easily adapt to constant social changes and successfully communicate in multicultural professional environments. The research attempts to present the development of creative skills in students as a process associated with difficulties in its practical implementation. The article identifies popular tasks aimed at promoting creativity in EFL classes, lists the main difficulties that teachers face when using creative tasks, and suggests ways to overcome these difficulties.

It is a descriptive and analytical study of the existing pedagogical research on the interpretation of the concepts of creativity, creative thinking and creative 
abilities, as well as on the use of creative tasks in the EFL classroom. The scope of analysis included review articles advocating for creative skills in modern society published in 2001-2019. In addition, action research articles published over the past three years describing the experience of using creative tasks when teaching foreign languages were analyzed. In the course of the study, a set of methods was utilized: review, observations in conversational English classes with students majoring in linguistics, an expert survey of foreign language teachers generated on the Google Forms platform, and interpretation of the data obtained.

Keywords: creativity, innovations, divergent/convergent thinking, communicative creativity, tolerance to ambiguity

\section{Introduction}

When domestic and foreign researchers analyse the requirements for 'a modern specialist', a university graduate, they pay much attention to the development of unconventional creative thinking skills. The creativity concept has gained popularity in the last decade, although not exclusively in the scientific community. Business trainings, seminars, master classes, workshops etc. are devoted to the development of creative thinking skills. Creative tasks are firmly included in modern educational and methodological publications including those in a foreign language.

This article is aimed at presenting the development of students' creative skills in foreign language classes as a complex process associated with difficulties in practical implementation and representing a real challenge for teachers of foreign languages:

1. To substantiate the relevance of the development of creative thinking of students.

2. To demonstrate the connection between the creative potential and success of a young specialist in a contemporary innovative society.

3. To identify popular tasks for the development of creativity used in foreign language classes.

4. To find fundamental obstacles faced by teachers of foreign languages in using creative assignments.

5. To outline ways to overcome those obstacles.

The national doctrine of education of the Russian Federation (2000-2025) declares the need for the creative development of an individual at all stages of the educational process [National Doctrine, 2000]. This results in extensively introducing terms of creative educational tools in the foreign language 
classroom. The types and significance of such terms of creative engagement for increasing the motivation and interest of students etc. were considered in the literature [Richards, 2013; Maley, 2010; Kiseleva, 2017; Novikova, 2019]. However, the limiting factors of their practical application have not been sufficiently highlighted in scholarly papers. Based on our own experience and the experience of colleagues, this article will present creative assignments in foreign language classes as a challenge for teachers.

\section{Study material, research methodology and technique}

This article is a descriptive and analytical study of scientific literature on the interpretation of the concepts of creativity, creative thinking and creative abilities as well as the use of creative assignments in foreign language classes. The analysis included review articles in 2001-2019 that substantiated the need for creative skills in modern society and described the experience of using terms of creative engagement in teaching a foreign language. In total, one hundred articles in Russian published on the eLIBRARY.ru platform and one hundred articles in English published on the ScienceDirect platform over the past three years (2017- early 2020) were selected. In addition, the authors used observation methods in the classroom for a practical English course with students specialising in Linguistics and an expert survey of foreign language teachers with a questionnaire created on the Google Forms platform.

\section{Description of the research}

At the first stage, review articles were selected by the key words 'creativity' and 'creative thinking'. An analysis of the definitions of the studied concept was carried out, the main components of creativity were highlighted and the importance of this skill in modern society substantiated. Further, a selection and content analysis of articles was made using the keywords 'creativity' and 'foreign language learning'. At the next stage, we conducted an online survey of teachers of foreign languages in schools, higher educational institutions and private schools in Tyumen. The questionnaire included the questions as follows:

1. Do you consider it necessary to use assignments to develop creative skills and creativity in foreign language classes? (yes, no, I find it difficult to answer, other).

2. Do you use any tasks to foster creative skills in foreign language classes? (yes, no). 
3. How often do you use tasks to develop creative skills and creativity in foreign language classes? (in almost every class, sometimes, rarely, almost never).

4. At what stage of handling the material do you use tasks to develop creative skills? (at the stage of presentation of new material, at the stage of working out and solidifying new knowledge, at the production stage).

5 . In your opinion, what are the students' responses to creative assignments? (positive, rather positive, rather negative, other).

6. What level of proficiency in a foreign language, in your opinion, should students have in order for them to complete creative tasks? (any, A1, A2, B2 and higher).

7. In your opinion, are there enough terms of creative engagement in the learning and teaching support kit used by you? (not enough, enough, there are too many such tasks).

8. Do you have any difficulties in arranging and conducting creative assignments? (you can choose more than 1 option) (I don't have any, preparation takes too much time, it takes too much classroom time, it is difficult to organise students, I have difficulties in assessing this kind of assignment, other).

9. What types of creative tasks do you use in foreign language classes? ('brainstorming,' 'mind maps', crosswords, puzzles, logic puzzles etc., creative writing, dramatisation, project assignments etc.).

10. Do creative tasks contribute to more successfully mastering a foreign language? (no doubt, they do; not always; they contribute to the development of communication skills, creativity but not directly to mastering a foreign language).

Further, the survey results were processed. In discussing the results, the authors also took into account their own experience in working with creative assignments in English classes with university students in Tyumen.

\section{Research findings}

\subsection{Creativity as a multifaceted concept}

Researchers agree that creativity is a complex phenomenon that does not have one generally accepted definition. It implies the ability to create something (a product in the broadest sense, or an attitude to something) new, original, attractive, useful in certain conditions and allowing a person to adapt to an unknown situation. Creativity includes four components, such as subject, process, product and social environment [Runco, 2018]. Under the influence of a certain environment conducive to creative activity, 
a subject is included in the creative process as a result of which he/she creates an innovative product. The neurobiologist A. Dietrich from the American University of Beirut distinguishes four types of artistic and scientific creativity, i. e. deliberate cognitive, deliberate emotional, spontaneous cognitive, spontaneous emotional [Dietrich, 2004]. It was common to believe that creativity would be associated with divergent left-brain thinking but Dietrich proves that creative activity affects both hemispheres. For the creative activity, a certain minimum of general intelligence and the capacity to carry out cognitive activity are required. Deliberate creativity can be stimulated (by creating a favourable social and material climate) and developed (by special trainings, exercises), while spontaneous creativity cannot.

In the pedagogical area, in particular in teaching foreign languages, considered will be creativity in such aspects as creativity/creative activity in order to identify the innovative, adaptive and communicative potential of students and enhance their motivation; creativity of the teacher; student creativity; assignments that require student creativity; creativity to improve student motivation; creativity as a difficulty/challenge.

4.2. Creativity as a prerequisite for the innovative potential development

The heightened interest in developing creative thinking skills is due to several factors at the same time. In our opinion, the research into creativity has been relevant and in demand primarily in the context of the intensive development of innovative processes in our country, since creativity means 'creativity embodied in innovation' [Il'in, 2009]. Such an innovative understanding of creativity makes it an integral component of innovation [Panova, 2015]. It is noteworthy that the very concept of 'innovation' originally had an exclusively cultural meaning and was used to denote the introduction of components of one culture into another, in particular, it was about the introduction of European traditions into the colonial countries of Africa and Asia [Arenkov, 2001]. Not until the beginning of the XX century, the scope of the term shifted to the field of production technology, and then to the economic theory, personnel and production management and education. The famous American economist J. Schumpeter in the 1930s defined innovation as a change 'aimed at introducing and using new types of consumer goods, new production and transport vehicles, markets and forms of organisation in industry' [Schumpeter, 1982]. Depending on the object and subject of research in the XXI century. innovation can be viewed as a new product creation process, as a result, i.e. the implemented innovation, or as innovation 
as such - innovation, discovery, invention, ideas [Kharin, 2016; Panova, 2015]. According to Schumpeter, innovation is the main source of profit [Schumpeter, 1982]. This statement is more relevant than ever these days. In the current context, to increase the competitiveness of an enterprise, intangible resources and assets (innovative developments, for which there are exclusive rights, know-how, production secrets etc.) are sometimes more significant than the benefits of a tangible nature [Kishko, 2017, 6]. Thus, it is the intellectual rather than tangible advantages (ideas related to goods, not their production) that increase competitiveness. Creativity embodied in innovation makes it possible for a company to move to a new, higher stage of development by 'ensuring its new qualitative state and, accordingly, its movement forward. Such an entity enters the market 'with new materials, goods, services, technologies' [Spivak, 2003, 231].

Creative solutions and innovations ensure the successful development of not only individual companies but also the country's economy as a whole [Markman, 2015]. The importance of innovations for achieving the goals of our country's long-term development is described in detail in the draft strategy for innovative development of the Russian Federation for the period up to 2020, 'Innovative Russia 2020'. The pivotal role of innovations can be explained by the fact that the transition of the economy to an innovation-driven growth model is declared the only possible way to achieve the long-term development goals, to ensure the well-being of the population and consolidate the country's geopolitical position on the global stage. Modern external challenges necessitate intensifying efforts to develop innovations. First, the key challenges include the acceleration of the world economy's technological development, the technological revolution in alternative energy, resource conservation, the development of technologies for oil and gas production from unconventional sources (shale, oil sands). Secondly, the increased competition in the world for a highly qualified workforce and 'smart' money (investments in projects related to new knowledge, technologies etc.). Thirdly, the new millennium offers challenges that all of humanity is facing, such as food security, population aging and health challenges, climate change. These challenges necessitate the development of special areas of research, e.g. genomic medicine, 'clean' energy etc. The authors of the above project regretfully state the preservation of the raw material nature of the Russian economy, Russia's belonging to the category of countries with an innovative system of imitation type that is incapable of any regular production of new knowledge. 


\subsection{Creativity as a prerequisite for adapting to uncertainty}

The second reason for the growing popularity of creativity is its connection with human adaptive abilities. Perhaps the main property of an 'innovative person' is called his/her ability to adapt to constant changes in personal or social life, economic development or the development of science and technology. For the relationship between the indicators of creativity and tolerance/intolerance to uncertainty, see [Pavlova, 2012], [Lyubart, 2009]. A creative person will be less resistant to and traumatised by change.

In general, the phenomenon of resistance to change associated with the psychological characteristics of human consciousness, psychological insensitivity to something new and true innovations is a great obstacle to the modernisation of both the education system and other institutions of modern Russia. A positive attitude towards change is especially relevant in our time of socio-economic and scientific-technical changes. It allows one to avoid trauma and to adapt to an ongoing process of change.

A member of modern society should also act as an active initiator and producer of change. The key competencies of an 'innovative person' should include the ability for lifelong learning, continuous self-improvement, critical thinking, willingness to take reasonable risks, the ability to work both independently and in a team in a highly competitive environment, and, finally, creativity [Government of the Russian Federation, 2011].

4.4. Creativity as a major driver for successful intercultural communication

Another factor to emphasise the development of the creative potential of an individual is the connection between the creativity of mental activity and the creativity of interpersonal communication. Professional communication in the XXI century often occurs in a multicultural environment. Such communication will be more successful if its participants have a certain type of thinking 'which is inherent in a flexible, original and immediate response to a problematic situation' [Kashapova, 2013, 42]. This flexibility can be better shown by those who have experience in intercultural communication and another culture [Bouncken, 2009], [Berardo, 2012], [Leung, 2008]. They see more alternatives for solving problems, represent objects of the surrounding reality, people and situations from several points of view at the same time.

The creative potential of a person can be manifested in all areas of the individual's communication activities, also in the field of interpersonal interaction. In this case, we are talking about social creativity or creative communication, which is defined as communication between people based on 
a 'problematic situation causing mutual stimulation of the participants and accompanied by the new idea generation' [Golovanova, 2013, 8]. The 2013 research identified a statistical relationship between creative thinking and creative communication meaning that a person who easily generates ideas in the field of thinking 'will be more mobile and variable in the interpersonal communication situations' which contributes to a higher efficiency of joint actions [Golovanova, 2013, 11]. In the 2017 research, a relationship between social creativity and young professionals' pursuance of realisation of personal potential was established [Kushchazli, 2015].

So, the need to develop creative thinking is associated with the Russian economy's growing demand for

1. innovations (innovation creativity);

2. persons who are capable of comfortably adapting to constant social changes (creativity as tolerance to uncertainty);

3. persons who possess the skills of successful communication in a multicultural professional environment (creativity as a guarantee of successful intercultural communication).

4.5. Creativity in foreign language classes

The topic of creativity in teaching foreign languages in Russia has been addressed relatively recently. It seems that interest in it has already begun to decline. So, in 1998-2001, on the eLIBRARY.ru platform, there was only one article in which creativity was placed in the title or key words. In 20072010, there were as many as 18 such articles. From 2011 to 2016, 46 articles and in 2017-2019, 20 articles were shown on request. For comparison, on the ScienceDirect platform in 2017-2019, 21 articles dedicated to describing the experience of European, Asian and Arabic teachers of English could be found. A general increase in the number of scientific articles on creativity has been observed since 2005. Below, see the number of articles on various aspects of creativity in Russian and foreign publications.

\section{Interpretation of research results}

The articles by Russian authors discuss the creation of conditions in foreign language classes that contribute to the disclosure of the creative potential of students. Major emphasis is put on creating a friendly and comfortable setting during the lesson. The main role in this is assigned to the teacher, who is required to show a pedagogical tact as well as to accept the new pedagogical realities, in which the teacher is no longer just a knowledge catalyst but an aca- 
Table 1

Number of articles on aspects of creativity in foreign language classes in Russian and foreign journals in 2017-2019 posted on the eLIBRARY.ru and ScienceDirect platforms

\begin{tabular}{l|c|c}
\hline \multicolumn{1}{c|}{ Aspect of creativity } & $\begin{array}{c}\text { Number of articles } \\
\text { on eLIBRARY.ru }\end{array}$ & $\begin{array}{c}\text { Number of articles } \\
\text { on ScienceDirect }\end{array}$ \\
\hline Creativity of the teacher & 4 & 11 \\
\hline Student creativity & 5 & 2 \\
\hline $\begin{array}{l}\text { Assignments requiring student } \\
\text { creativity }\end{array}$ & 5 & 3 \\
\hline Creativity to encourage students & 1 & 2 \\
\hline $\begin{array}{l}\text { Creativity in teaching a foreign } \\
\text { language for special purposes }\end{array}$ & 5 & 2 \\
\hline Creativity as a difficulty / challenge & 0 & 21 \\
\hline Articles, total & 20 & \\
\hline
\end{tabular}

demic mentor, a facilitator/consultant. In general, many articles are focused on the development of teacher's creativity, where the main qualities of a creative teacher are considered and the importance of these qualities is emphasised [Matsak, 2018]. A number of studies analyse the cross-cultural communicative creativity development problem. It is interesting that the authors note using the communicative creativity skills even at the initial stage of learning a foreign language [Dmitrieva, 2017]. A considerable number of articles describe the use of various creative tasks (group discussion, educational business game, project activities, the use of mobile technologies) [Bykhtina, 2017], [Savchenko, 2017]. It is important to note that issues related to the difficulties of using creativity development tasks are virtually not touched upon in the articles of Russian researchers. The only exception here is the study by A.I. Novikova et al. in which the authors point out the difficulties in assessing terms of creative engagement. During the research, the authors come to the conclusion that the assessment system in Russian higher education is aimed more at encouraging students' diligence than their creativity [Novikova, 2019].

National educational doctrines in Europe and Asia also proclaim creativity in education and creativity as a mandatory competence of students in the 21 st century. Despite this, the foreign community and the media are raising alarm that the contemporary education system is killing their 
creative abilities in children [McKinney, 2019]. At the same time, the creativity/creative activity phenomenon itself has not received an unambiguous definition. The complex and often inexplicable nature of this phenomenon leads to the fact that teachers find it difficult to understand how it should be developed in students [Egan, 2017], [Bereczki, 2018].

Lack of time and special training, an overloaded curriculum, insufficient resources, the need to prepare for standard tests, difficulties in assessing creative assignments are mentioned among the difficulties facing the teacher. Interesting is the way of teachers' perspectives on ICT technologies, half of them refer to the means that stimulate creative activity, while the other half has exactly the opposite opinion [Bereczki, 2018]. An Icelandic teacher, in describing the experience of using creative tasks, concludes the following difficulties that he and his colleagues encountered: maintaining a balance between control and freedom in the work of both the teacher and students, inspiring students' independence and professional teacher training in creative work techniques [Jonsdottir, 2017]. As for the relationship between the performance of creative tasks in foreign language classes and the level of language proficiency, only one experimental study conducted in Chinese primary schools showed a direct relationship between the performance of creative tasks in English lessons and their academic performance [Liao, 2018].

The questioning of teachers of foreign languages in Tyumen made it possible for us to supplement the overall picture of the relationship between the creativity of teachers, students and their language competence.

68 responses were received to the proposed questionnaire. The answers were distributed as follows, $92.6 \%$ of the respondents consider it necessary to use creative assignments in foreign language classes, $2.9 \%$ believe that such assignments are not needed. $35.3 \%$ of respondents use terms of creative engagement in almost every lesson, $32 \%$ do it sometimes, $17.6 \%$ rarely use it. Only $5.9 \%$ use such tasks at the stage of presentation of new material. A significant number of teachers use such tasks at the stages of material development and production (36.8 \% and $57.4 \%$, respectively). $97 \%$ of teachers believe that students perceive terms of creative engagement positively. Most of the teachers (64.7\%) believe that students with any level of foreign language proficiency will cope with terms of creative engagement; $20.6 \%$ of respondents believe that creativity in a foreign language requires a very high level of foreign language competence. Teachers were almost equally separated according to the degree of satisfaction with the number of terms 
of creative engagement in the teaching and methodological materials used by them ( $54.4 \%$ are satisfied and $44.1 \%$ are not satisfied). As for the difficulties in carrying out creative assignments, almost half ( $48.5 \%)$ noted the laboriousness of the preparation process, about one third (26.5\%) of the cost of classroom time and the difficulty in organising students (23.5\%). About a third of teachers $(36.8 \%)$ do not experience any difficulties. $23.5 \%$ indicated difficulties in assessing such tasks. When asked about the types of creative tasks used, the majority (79.4\%) chose the project methodology; about half of teachers use 'brainstorming', 'mental maps, crosswords, puzzles etc. and creative writing. Only $38.2 \%$ use dramatisation and $3 \%$ chose 'other'. $38.2 \%$ of respondents believe that terms of creative engagement are not directly related to mastering a foreign language competence; $61.8 \%$ are of the opinion that tasks for using a creative approach undoubtedly contribute to fostering language skills. The overwhelming majority of survey participants have over 15 years of teaching experience and work with both linguistic and non-linguistic students, as well as schoolchildren in public and private schools.

\section{Conclusions}

The rather large volume of research papers appearing in foreign publications (about 300 per year), in one way or another related to creativity in education, testifies to the high interest of teachers in creative activities. Relatively fewer articles are devoted specifically to the use of creative assignments in foreign language classes. Insufficient data are available on the direct impact of such assignments on foreign language proficiency as measured by traditional academic means.

Among the difficulties that teachers face in foreign language classes in higher education, those are the laboriousness and energy consumption in preparing, conducting and evaluating such tasks and the complexity of organising students. Students perceive these assignments differently, from enthusiasm to discontent. It depends on their personal cognitive characteristics, for some it is easier to be given tasks on the use of artistic creativity, for others on the use of scientific creativity. Some are accustomed to autonomous work, concentrated mental activity and that means they are ready for deliberate creativity. Other students feel more comfortable in a team, are liberated in expressing their thoughts, i. e. more adapted to spontaneous creativity. These factors should be taken into account by the teacher. 
Terms of creative engagement make both the teacher and student step out of their comfort zone; as a result, they can have both a positive (feeling of relaxedness, freedom of expression) and a negative impact (a situation of uncertainty, chaos). They can cause stress for both the teacher and student. The problem of difficulties in the practical application of creative assignments in foreign language classes is poorly covered in Russian literature. In addition, despite a large number of articles focusing on the creativity of teachers, in our opinion, proper attention is not paid directly to the ways of developing the creative potential of teachers.

From our own experience, we can assert that creative tasks are difficult for a teacher for several reasons:

1) knowledge and understanding of the nature of creative activity is required;

2) there needs to be a change in your own approach to organising classes, acceptance of creativity as an integral part of the pedagogical process;

3 ) it is necessary to take into account the personal characteristics of students;

4) additional personal time is needed to be spent on preparing assignments;

5) it is necessary to develop a system for evaluating creative assignments (usually it is not presented in teaching materials on a foreign language);

6) it is necessary to create an atmosphere conducive to creativity, which can be difficult in too small or too large classrooms with an arrangement of desks, when students sit with their backs to each other;

7) classrooms need to have certain materials and technical supplies (computers, multimedia equipment, smart board and Internet access);

8) a balance between the freedom of creativity of students and the control of the creative process is needed.

As an aid to teachers, we propose to conduct regular professional and psychological training on the creative activity specifics, change the interior of classrooms, and possibly add some creative tasks in the independent work.

\section{Conflict of Interest}

The authors have no conflict of interest to declare.

\section{References:}

1. Natsional'naya doktrina obrazovaniya v Rossiyskoy Federatsii do 2025 goda [National Doctrine of Education in the Russian Federation until 2025] (2000). http:// 
sch1231.mskobr.ru/files/nacional_naya_doktrina_obrazovaniya_v_rossijskoj_federacii_utverzhdena_postanovleniem_pravitel_stva_rf_ot_04_10_2000_751.pdf

2. C. Richards. Creativity in language teaching. Iranian Journal of Language Teaching Research, No 1(3) (2013), pp. 19-43.

3. A. Maley, N. Peachy. Creativity in the English language. British council. Teaching English (2010). https://www.teachingenglish.org.uk/sites/teacheng/files/ pub_F004_ELT_Creativity_FINAL_v2\%20WEB.pdf

4. Z. A. Kiseleva. Povysheniye motivatsii dostizheniya studentov na zanyatiyakh po inostrannomu yazyku posredstvom tvorcheskikh zadaniy [Improving the Motivation of Students to Achieve in Foreign Language Classes through Creative Assignments]. Voprosy metodiki prepodavaniya v vuze [Questions of teaching methods in high school], Vol. 6, № 20 (2017), pp. 94-100.

5. I. A. Novikova, A. L. Novikov, N. S. Berisha. Kreativnost' studentov i uspekh $\mathrm{v}$ izuchenii inostrannogo yazyka: paradoksy pedagogicheskogo otsenivaniya [Student creativity and success in learning a foreign language: paradoxes of pedagogical assessment]. Vysshaya shkola: opyt, problemy, perspektivy. Materialy XII Mezhdunarodnoy nauchno-prakticheskoy konferentsii [Higher school: experience, problems, prospects. Proceedings of the XII International scientific-practical conference]. Peoples' Friendship University of Russia, Moscow (2019), pp. 168-172.

6. M. Runco. The Four Ps of Creativity: Person, Product, Process, and Press (2018). http: https://www.researchgate.net/publication/325981320_The_Four_Ps_of_Creativity_Person_Product_Process_and_Press. 10.1016/B978-0-12-809324-5.06193-9

7. A. Dietrich. The Cognitive Neuroscience of Creativity. Psychonomic Bulletin \& Review. Vol. 11, Issue 6 (2004), pp. 1011-1026.

8. E. P. Il'in. Psikhologiya kreativnosti i odarennosti [Psychology of creativity, giftedness]. Piter, Staint Petersburg (2009).

9. E. S. Panova. Kreativnost': istoki, idei, realizatsiya [Creativity: Origins, Ideas, Implementation]. Direkt-Media, Moscow (2015).

10. I. A. Arenkov, P. F. Baum, V. V. Tomilov. Innovatsionnyy potentsial firmy: strategiya razvitiya [The Innovative Potential of the Company: Development Strategy]. SPbSUEF, Saint Petersburg (2001).

11. J. Schumpeter. Teorii ekonomicheskogo razvitiya [Theories of Economic Development]. Progress, Moscow (1982).

12. A. A. Kharin, I. L. Kolensky. Upravleniye innovatsiyami [Innovation Management]. Vysshaya shkola, Moscow (2016).

13. A. V. Kishko, A. N. Mayorova. Nematerial'nyye faktory konkurentosposobnosti roznichnykh torgovykh organizatsiy [Intangible Factors of Competitiveness 
of Retail Trade Organizations]. Rossiyskiy ekonomicheskiy internet zhurnal [Russian Economic Internet Journal], No. 4 (2017). http://www.e-rej.ru/Articles/2017/ Kishko_Mayorova.pdf

14. V. A. Spivak. Ideal'nyy rukovoditel', ideal'nyy predprinimatel' [An Ideal Leader, an Ideal Entrepreneur]. NEVA, St. Petersburg (2003).

15. A. Markman. To Get More Creative, Become Less Productive. Harvard Business Review (2015). https://hbr.org/2015/11/to-get-more-creative-become-less-productive

16. E. M. Pavlova, T. V. Kornilova. Kreativnost' i tolerantnost' k neopredelennosti kak prediktory aktualizatsii emotsional'nogo intellekta v lichnostnom vybore [Creativity and Tolerance to Uncertainty as Predictors of The Actualization of Emotional Intelligence in Personal Choice]. Psikhologicheskiy zhurnal [Psychological Journal], No. 33 (5) (2012), pp. 39-49.

17. T. Lyubart, K. Mushiru, S. Thorjman, F. Zenasni. Psikhologiya kreativnosti [Psychology of Creativity]. Kogito-Center, Moscow (2009).

18. Strategiya innovatsionnogo razvitiya Rossiyskoy Federatsii na period do 2020g. Rasporyazheniye Pravitel'stva RF [The Strategy of Innovative Development of The Russian Federation for the Period until 2020: Order of the Government of the Russian Federation], No. 2227 (2011). http://static.government.ru/media/ files/4qRZEpm161xctpb156a3ibUMjILtn9oA.pdf

19. M. M. Kashapova, T. G. Kiseleva, T. V. Ogorodova. Kreativnost' kak klyuchevaya kompetentnost' pedagoga [Creativity as a Key Competency of a Teacher]. Indigo, Yaroslavl (2013).

20. R. Bouncken. Creativity in Cross-Cultural Innovation Teams: Diversity and Its Implications for leadership. Milieus of Creativity, Knowledge and Space. Chapter 9 (2009), pp. 189-200.

21. K. Berardo. The Connection between Creativity and Intercultural Competence. Cultural Detective Blog (2012). https://blog.culturaldetective.com/2012/05/03/ the-connection-between-creativity-and-intercultural-competence/

22. A. K. Leung, W. W. Maddux, A. D. Galinsky, Ch. Chiu. Multicultural Experience Enhances Creativity: The When and How. American Psychologist, No 63 (3) (2008), pp. 169-181.

23. A. A. Golovanova. K probleme diagnostiki sotsial'noy kreativnosti [To the Problem of Diagnosing Social Creativity]. K probleme diagnostiki sotsial'noy kreativnosti [Bulletin of the Saratov University. New series. Acmeology Education Series. Developmental psychology], Vol. 2. No. 1 (2013), pp. 7-12.

24. M. I. Kushchazli. Osobennosti vzaimosvyazi kreativnosti i samorealizatsii molodykh issledovateley [Features of the Relationship of Creativity and Self-Reali- 
zation of Young Researchers]. Internet magazine "Mir nauki", Vol. 5. No. 6 (2015). https://mir-nauki.com/PDF/77PSMN617

25. T. V. Matsak, I. F. Petrov. Kreativnost' kak odno iz vazhneyshikh kachestv budushchego pedagoga inostrannogo yazyka [Creativity as One of the Most Important Qualities of a Future Teacher of a Foreign Language]. Alleya nauki, Vol. 2. No. 10 (26) (2018), pp. 555-569.

26. E. V. Dmitrieva, G. V. Terekhova. Razvitiye krosskul'turnoy kommunikativnoy kreativnosti studentov universiteta pri obuchenii inostrannomu yazyku [The Development of Cross-Cultural Communicative Creativity of University Students in Teaching a Foreign Language]. Strategicheskiye napravleniya razvitiya obrazovaniya v orenburgskoy oblasti. Nauchno-prakticheskaya konferentsiya s mezhdunarodnym uchastiyem [Strategic directions for the development of education in the Orenburg region. Scientific and practical conference with international participation] (2017), pp. 82-87.

27. N.V. Bykhtina. Uchebnaya delovaya igra kak usloviye razvitiya sotsial'noy i kommunikativnoy kreativnosti obuchayushchikhsya (na primere inostrannogo yazyka) [Educational Business Game as a Condition for the Development of Social and Communicative Creativity of Students (Exemplified by a Foreign Language Class)]. Professionally-oriented teaching of a foreign language in higher education educational organizations of the Ministry of Internal Affairs of Russia: traditions and innovations. Abstracts of the Interdepartmental Scientific and Practical Conference (2017), pp. 48-54.

28. E. V. Savchenko. Uchebnaya delovaya igra kak usloviye razvitiya sotsial'noy i kommunikativnoy kreativnosti obuchayushchikhsya (na primere inostrannogo yazyka) [Mobile Technologies as a Tool for the Development of Innovative Competence and Creativity of Students exemplified by the Discipline "Foreign Language" In Higher Education]. Professional'no-oriyentirovannoye obucheniye inostrannomu yazyku v obrazovatelnykh organizatsiyakh vysshego obrazovaniya MVD Rossii: traditsii i innovatsii. Sbornik tezisov Mezhvedomstvennoy nauchno-prakticheskoy konferentsii [Innovative competencies and creativity in psychology and pedagogy. Collection of articles following the results of the International scientific-practical conference] (2017), pp. 81-84.

29. Ph. McKinney. Innovation in America: How Our Education System Hampers Creativity. (2019). Philmckinney.com. https://philmckinney.com/innovation-in-america-how-our-education-system-hampers-creativity-2/

30. A. Egan, R. Maguire, L. Cristophers, B. Rooney. Developing Creativity in Higher Education for $21^{\text {st }}$ Century Learners: A Protocol for a Scoping Review. International Journal of Educational Research, Vol. 82 (2017), pp. 21-27. 
31. E. O. Bereczki, A. Kárpáti. Teachers' Beliefs about Creativity and its Nurture: A Systematic Review of the Recent Research Literature. Educational Research Review, Vol. 23 (2018). pp. 25-56.

32. S. R. Jonsdottir. Narratives of Creativity: How Eight Teachers on Four School Levels Integrate Creativity into Teaching and Learning. Thinking Skills and Creativity, Vol. 24 (2017), pp. 127-139, 10.1016/j.tsc.2017.02.008

33. Yu-H. Liao, Yi-L. Chen, Hsue-C. Chen, Yu-L. Chang. Infusing Creative Pedagogy into an English as a Foreign Language Classroom: Learning Performance, Creativity, and Motivation. Thinking Skills and Creativity, Vol. 29 (2018), pp. 213-223.

DOI 10.15826/B978-5-7996-3081-2.05

\title{
Creative Speech Making as One of the Goals of Teaching a Foreign Language
}

\author{
Mikhailova Svetlana', Zaitseva Alena ${ }^{2}$ \\ ${ }^{1}$ Institute of the Foreign Languages, State Autonomous Educational Institution \\ of Higher Education of Moscow, Moscow City Pedagogical University, \\ Moscow, Russia \\ ${ }^{2}$ Institute of the Foreign Languages, State Autonomous Educational Institution \\ of Higher Education of Moscow, Moscow City Pedagogical University, \\ Moscow, Russia \\ Corresponding author: Mikhailova Svetlana, jevouslis@mail.ru
}

\begin{abstract}
Creativity is one of the human competencies, the development of which is based on individual aspects. Creative writing as a component of a creative linguistic personality is a set of knowledge about the language, individual characteristics of written production and the ability to creative self-expression. In the study of a foreign language, the formation of a secondary linguistic personality occurs, in our opinion, through speech-creative self-realisation, which determines the linguodidactic potential of creative writing.

Keywords: linguodidactics, creativity, creative writing, secondary linguistic personality, foreign language teaching content
\end{abstract}

